\title{
The Effectiveness of Non-Surgical Weight Management Interventions for Obesity in the UK: A Review and Meta-Regression Analysis
}

\author{
Jason Randall ${ }^{*}$, Matt Slater ${ }^{1}$, Antony Stewart ${ }^{1}$, Geoff Pugh ${ }^{2}$, Kevin Lewis ${ }^{3}$, Cathy Levy33, \\ Paola Alessandri-Gray ${ }^{3}$ \\ ${ }^{1}$ Centre of Sport, Health and Exercise Research, Faculty of Health Sciences, Staffordshire University, \\ Staffordshire, UK \\ ${ }^{2}$ Business School-Research \& Enterprise, Faculty of Business, Education and Law, Staffordshire University, \\ Staffordshire, UK \\ ${ }^{3}$ Public Health Department, Shropshire County Council, Shrewsbury, UK \\ Email: " j.a.randall@staffs.ac.uk
}

Received 22 January 2014; revised 22 February 2014; accepted 2 March 2014

Copyright (C) 2014 by authors and Scientific Research Publishing Inc.

This work is licensed under the Creative Commons Attribution International License (CC BY).

http://creativecommons.org/licenses/by/4.0/

(c) (i) Open Access

\begin{abstract}
Background: Obesity is regarded as one of the most serious challenges public health faces in the $21^{\text {st }}$ century for adults and children alike. Accordingly weight management interventions remain a public health priority aiming to reduce the burden of obesity and co-morbidities. Therefore this review aims to assess the effectiveness of non-surgical weight management interventions for obesity in the UK. Method: Thirty one databases were searched that identified 20 articles for inclusion. Articles were screened and quality scored using the "Effective Public Health Practice Project Quality Assessment Tool". Meta-regression analysis (MRA) was undertaken on seven studies that allowed for effect size calculations. Results: In adult populations, lifestyle interventions that targeted both diet and physical activity, delivered in the private sector were most effective in reducing weight and/or BMI, and were more cost-effective. In children the most successful interventions mirrored adult interventions, but were family-orientated. MRA supported these findings. Most frequent intervention duration was 12 weeks. Discussion: The results provide evidence to support policy makers for the effective delivery of weight management interventions. Findings suggest that weight management interventions in the UK are effective in reducing weight and/or BMI for both children and adults. Interventions delivered in the private sector (e.g. Weight Watchers), targeting diet and physical activity levels, demonstrated the highest levels of effectiveness. However, compared to these models, NHS programmes are less well defined in the research literature
\end{abstract}

*Corresponding author.

How to cite this paper: Randall, J., Slater, M., Stewart, A., Pugh, G., Lewis, K., Levy, C. and Alessandri-Gray, P. (2014) The Effectiveness of Non-Surgical Weight Management Interventions for Obesity in the UK: A Review and Meta-Regression Analysis. Open Journal of Medical Psychology, 3, 235-249. http://dx.doi.org/10.4236/ojmp.2014.33025 
and may not have been optimised. For children, effectiveness is improved by family-level programmes incorporating children and their parents.

\section{Keywords}

\section{Health, Meta-Regression, Non-Surgical, Obesity, Weight Management}

\section{Introduction}

Obesity is an ever growing concern for both adults and children alike. In the UK, it has been reported that 25\% of UK adults are obese, whilst a further $41 \%$ of men and $32 \%$ of females are overweight [1]. With regard to children (aged under 16), 31\% of boys and 29\% of girls are classed as either overweight or obese [2]. Obesity in children is stated as one of the most serious challenges in the $21^{\text {st }}$ century [3]. Indeed, McQuigg et al. (2008) concluded that weight management interventions should be a public health priority to alleviate the burden of disease in the general population.

Weight-related morbidity and mortality has a significant impact on individuals' quality of life with associated risks such as cancer and cardiovascular disease and places a large burden on the NHS [4] [5]. Indeed, McCormick and Stone (2007) estimate the annual cost to the NHS of obesity and relating morbidities as between £991-1124 million. Amidst various solutions, physical activity (PA) is becoming an increasingly important intervention to reduce a variety of chronic diseases [6]. As a consequence, tackling inactivity is paramount and has the potential to have a substantial impact on public health [3] [7]. This exemplifies the importance of interventions that target PA behaviour change. The relatively low cost and minimal side-effects in comparison to clinical and pharmacological interventions further support the adoption of interventions targeting behaviour change in levels of PA.

Previous reviews of weight management interventions have generally concluded that engagement in PA programmes is successful in reducing weight [8] [9], and that in child population success is greatly improved when adults are targeted in a family-level intervention [3]. More specifically, weight management interventions with a family focus (i.e., those that target children and parents) can significantly increase the likelihood of successful and maintained weight loss [10]. Despite various reviews being undertaken in the area, the focus of these articles has generally been on world-wide weight management interventions, and thus a review focusing solely on UKbased interventions would add to our knowledge base and provide a specifically tailored account for UK policy makers and regional Public Health departments.

As such, the primary purpose of the following investigation is to undertake a review and meta-regression analysis of research articles that have examined non-surgical weight management interventions within the UK in both adult and child populations. Second, it is hoped the results will help to provide an evidence base to inform a payment by results tariff suitable for UK weight management interventions. Finally, meta-regression would allow for quantitative identification of the effect size as well as identifying possible confounding factors.

\section{Method}

\subsection{Inclusion Criteria}

1) Published in English.

2) Published in a peer reviewed journal for quality assurance.

3) Weight management intervention (excluding surgery).

4) Undertaken within the UK.

5) Included obese participants representative of the general UK population.

6) Weight management is the main research area of the study.

\subsection{Search Strategy}

Thirty-one databases were searched including: Annual Reviews, Applied Social Science Index and Abstracts, BHI Net (British Humanities Index), BIDS (ingenta connect), Clinical Evidence, Cochrane Central Register of Controlled Trials, Cochrane Database of Systematic Reviews, DARE, Education Research Complete, ERIC full text, EPPI Centre databases, Index to THESES, JSTOR, LibWeb, Medline, NetLibrary, Oxford Reference 
Online: ProQuest, PsychARTICLES, PsychINFO, Science Direct, Social Care Online, Sociological Abstracts, Social Policy and Practice, Social Science Citation Index, Swetswise, Web of Knowledge, Web of Science, Wiley Interscience and ZETOC. The search was undertaken in August, 2012. The individual search terms, and various sequences of the following were inputted; "obesity", "weight management", "weight loss", "weight programm", "weight intervention". In total, 38,217 titles were manually screened by two researchers and 154 abstracts were identified for possible inclusion. From these abstracts, 35 articles received in-depth screening resulting in a final sample of 20 articles (see Tables 1 and 2). All articles were reviewed independently by the first and second authors. Figure 1 shows a detailed flow diagram of the inclusion process.

\subsection{Analysis}

Study quality was determined using the "Effective Public Health Practice Project Quality Assessment Tool” [11] [12], which has been used in a wide range of public health reviews [13]. The quality of each article was assessed independently by the first and second authors. Scores were compared and any disparities were discussed with the third author until a consensus was reached. The main variables for which data were sought were type of study design, participants and settings, type of intervention, effectiveness, cost-effectiveness, and study quality.

\section{Results}

\subsection{Type of Study Design}

A total of twenty articles were identified and included in the review. Of these, fourteen involved adult and six involved children participants. In terms of study design, of the adult articles eight were cohort, four were RCT, one was cohort analytical, and one was observational. Of the child articles, four were cohort, and two were RCT. Unlike other fields of research the high number of cohort studies is deemed a negative, although, the practical nature of the interventions means that often RCTs are impractical and inappropriate [3].

\subsection{Participants and Settings}

The studies used a range of participants; most used participants from NHS-managed organisations. Twelve of the adults studies included participants from NHS-based interventions [13]-[24] the remaining two studies used participants from the general population [25] [26]. From the articles investigating children, three used participants from the NHS [27]-[29] whilst three recruited from the general population [30]-[32].

\subsection{Type of Intervention}

The type of intervention delivered varied across the studies. From the fourteen adult articles, four delivered interventions in the private sector, whilst nine were administered in the public sector. Jolly et al. (2011) assessed a selection of interventions from the private and public sector. Notably, the most frequently adopted intervention was a lifestyle-based programme consisting of PA and nutrition management elements [18] [24]-[26] [33], whilst GP up-skilling was used in three papers [17] [20] [23]. Private sector programmes such as Weight Watchers [15] [34] and Slimming World [15] [16] were also popular. The following interventions were all used once: The Camelon Model [14], Rosemary Conley [15], NHS group weight loss programme [15], GP one-toone support [15], pharmacist one-to-one help [15], calorie restriction [21] and PA management [22].

The content of the interventions targeting weight loss in children mirrored the lifestyle approach utilised by many of the adult programmes. That is, a focus on PA and nutrition. The scope was broader with a family-centred approach aiming to promote behaviour change beyond the obese child in question. Five interventions were group-based consisting of various models, with four of these using acronyms; the MEND approach was used twice [30] [31], GOALS was used once [32], and FBBT was used once [27] whilst a general lifestyle improvement approach was taken by Edwards et al. (2006). Finally, the remaining article used a NHS one-to-one based intervention [29].

\subsection{Effectiveness}

Specific information on weight loss and success of each intervention detailed within the studies can be found in Table 1 (adult articles) and Table 2 (child articles). Broadly, interventions were effective in the adult population, 
Table 1. Description of adult articles.

\begin{tabular}{|c|c|c|c|c|c|c|}
\hline $\begin{array}{l}\text { Author/ } \\
\text { Date }\end{array}$ & Sample & $\begin{array}{l}\text { Method, } \\
\text { conditions and } \\
\text { outcome } \\
\text { measures }\end{array}$ & Intervention & Findings & Effect & $\begin{array}{l}\text { Quality } \\
\text { score }\end{array}$ \\
\hline $\begin{array}{l}\text { Ahern, Olson, } \\
\text { Aston, and } \\
\text { Jebb (2011) }\end{array}$ & $\begin{array}{l}\text { NHS referral } \\
\text { Scheme } n= \\
29,326 \text { (female } \\
=26,252), \\
\text { median age } 49 \\
\text { years, median } \\
\text { BMI = 35.1\% }\end{array}$ & $\begin{array}{l}\text { Observational } \\
\text { data } \\
\text { retrospectively } \\
\text { analysed. Twelve } \\
\text { WW sessions. } \\
\text { Weight (kg) }\end{array}$ & $\begin{array}{l}\text { Twelve sessions of WW at } \\
\text { a cost of } £ 45 \text { per } \\
\text { participant to the NHS. }\end{array}$ & $\begin{array}{l}\text { Median weight change for } \\
\text { all referrals was }-2.8 \mathrm{~kg} \text {. } \\
\text { t Those on first referral lost } \\
\text { more losing median of }-5.4 \\
\mathrm{~kg}(5.6 \% \text { of initial weight). } \\
\text { A third lost } \geq 5 \% \text { of initial } \\
\text { body weight. }\end{array}$ & N/A & Weak \\
\hline $\begin{array}{l}\text { Carroll, } \\
\text { Marshall, } \\
\text { Borkoles, } \\
\text { Ingle, Barker } \\
\text { and Tan } \\
\text { (2007) }\end{array}$ & $\begin{array}{l}\text { Premenopausal } \\
\text { females, } n=13 \\
(\text { females }=13 \text { ), } \\
\text { mean age } 40.9 \\
\text { years, mean } \\
\text { BMI = 39.2 }\end{array}$ & $\begin{array}{l}\text { RCT } \\
\text { lifestyle } \\
\text { intervention }(\mathrm{n}= \\
\text { 6), control }(\mathrm{n}=7) \\
\text { BMI, body fat, } \\
\mathrm{VO}_{2} \text {, BP, HR, } \\
\text { RER }\end{array}$ & $\begin{array}{l}\text { Lifestyle intervention, } \\
\text { based on self } \\
\text { determination theory } \\
\text { targeting PA and eating } \\
\text { behaviour. Advised to do } \\
\text { four hours self-chosen } \\
\text { exercise and two } \\
\text { structured exercise session } \\
\text { per week, } 30 \text { minutes } \\
\text { walking per day. Three } \\
\text { months followed my nine } \\
\text { months maintenance. }\end{array}$ & $\begin{array}{l}\text { No significant reduction in } \\
\text { body weight or any other } \\
\text { characteristics (BP, HR, } \\
\text { RER), between the control } \\
\text { and intervention. }\end{array}$ & N/A & Weak \\
\hline $\begin{array}{l}\text { Counter } \\
\text { Weight } \\
\text { Project } \\
\text { Team (2004) }\end{array}$ & $\begin{array}{l}\text { GP practice } \\
\mathrm{n}=80, \mathrm{UK} 62 \\
\text { practices } \\
\text { included and } \\
18 \text { acted as } \\
\text { control. } \\
\text { Patients } \\
\text { recruited } \mathrm{n}= \\
1256 \text { mean age } \\
50.6 \text { years, } \\
\text { mean BMI } 36.9\end{array}$ & $\begin{array}{l}\text { Cohort analytical. } \\
\text { GP practice staff } \\
\text { retrained. Success } \\
\text { of practice } \\
\text { monitored via } \\
\text { patient } \\
\text { recruitment and } \\
\text { weight change. }\end{array}$ & $\begin{array}{l}\text { Practice up skilling and } \\
\text { retraining to deliver } \\
\text { sinterventions that include } \\
\text { self-monitoring, stimulus } \\
\text { control, eating behaviour, } \\
\text { cognitive restructuring, } \\
\text { nutrition education, and } \\
\text { relapse management. }\end{array}$ & $\begin{array}{l}93.5 \% \text { of practices } \\
\text { successfully trained, } 75.8 \% \\
\text { actively recruiting. } \\
91 \% \text { of patients received } \\
\text { intervention. } 33 \% \text { showing } \\
\text { clinically beneficial weight } \\
\text { loss at } 12 \text { months, mean } \\
\text { reduction } 3.2 \mathrm{~kg} \text {. } \\
\text { Reductions seen } 3 \text { month } \\
-3.7 \mathrm{~kg}(\mathrm{n}=599) \text {, at } 6 \\
\text { months- } 4.3 \mathrm{~kg}(\mathrm{n}=388) \text { at } \\
12 \text { months }-3.2 \mathrm{~kg}(\mathrm{n}= \\
282) .\end{array}$ & N/A & Weak \\
\hline $\begin{array}{l}\text { Counter } \\
\text { Weight } \\
\text { Project } \\
\text { Team } \\
\text { (2005) }\end{array}$ & $\begin{array}{l}\text { GP practice } \\
\mathrm{n}=80, \mathrm{UK} .62 \\
\text { practices } \\
\text { included and } \\
18 \text { acted as } \\
\text { control } \\
\text { Patients } \\
\text { recruited } \mathrm{n}= \\
1549 \text { mean age } \\
49 \text { years, mean } \\
\text { BMI } 36.9\end{array}$ & $\begin{array}{l}\text { Cohort } \\
\text { GP practice staff } \\
\text { retrained. Success } \\
\text { of practice } \\
\text { monitored via } \\
\text { patient } \\
\text { recruitment and } \\
\text { weight change. }\end{array}$ & $\begin{array}{l}\text { Practice up skilling and } \\
\text { retraining to deliver } \\
\text { sinterventions that include } \\
\text { self-monitoring, stimulus } \\
\text { control, eating behaviour, } \\
\text { cognitive restructuring, } \\
\text { nutrition education, and } \\
\text { relapse management. }\end{array}$ & $\begin{array}{l}49 \% \text { classed as completers, } \\
\text { attending required appoints } \\
\text { at } 3,6 \text {, and } 12 \text { months. A } \\
\text { third of these achieved a } \\
\text { weight loss of } 5 \% \text { or more } \\
\text { at } 12 \text { months. Reductions } \\
\text { seen } 3 \text { month }-3.3 \mathrm{~kg}(\mathrm{n}= \\
728) \text {, at } 6 \text { months- } 4.2 \mathrm{~kg} \\
(\mathrm{n}=492) \text { at } 12 \text { months }-3.2 \\
\mathrm{~kg}(\mathrm{n}=445) \text {. }\end{array}$ & N/A & Weak \\
\hline $\begin{array}{l}\text { Counter } \\
\text { Weight } \\
\text { Project } \\
\text { Team (2008) }\end{array}$ & $\begin{array}{l}\text { GP practice } \\
\mathrm{n}=65 . \\
\text { Patients } \\
\text { recruited } \mathrm{n}= \\
1906 \text { (females } \\
=1468,77 \%) \\
\text { mean age } 49.4 \\
\text { years, mean } \\
\text { BMI 37.1. }\end{array}$ & $\begin{array}{l}\text { Cohort } \\
\text { GP practice staff } \\
\text { retrained. Success } \\
\text { of practice } \\
\text { monitored via } \\
\text { patient } \\
\text { recruitment and } \\
\text { weight change }\end{array}$ & $\begin{array}{l}\text { Practice up skilling and } \\
\text { retraining to deliver } \\
\text { interventions that include } \\
\text { sself-monitoring, stimulus } \\
\text { control, eating behaviour, } \\
\text { cognitive restructuring, } \\
\text { nutrition education, } \\
\text { physical activity } \\
\text { guidelines and relapse } \\
\text { management. }\end{array}$ & $\begin{array}{l}\text { At } 12 \text { months } 30.7 \% \text { of } \\
\text { attendees lost } 5 \% \text { of more of } \\
\text { their body weight. Females } \\
\text { lost average of } 2.8 \mathrm{~kg} \text {, males } \\
\text { lost } 3.4 \mathrm{~kg} \text {. At } 24 \text { months } \\
\text { average weight loss was } \\
-2.3 \mathrm{~kg},(\mathrm{n}=357) 31.9 \% \text { of } \\
24 \text { month attendees lost } 5 \% \\
\text { or more of total body } \\
\text { weight. Reductions seen } 3 \\
\text { month }-3.34 \mathrm{~kg}(\mathrm{n}=775) \\
\text { mean BMI change }-1.22 \text {, at } \\
6 \text { months - } 4.24 \mathrm{~kg}(\mathrm{n}= \\
548) \text { mean BMI change } \\
-1.55 \text { at } 12 \text { months }-2.96 \\
\mathrm{~kg}(\mathrm{n}=642) \text { mean BMI } \\
\text { change }-1.08 \text {. }\end{array}$ & $\begin{array}{l}\text { BMI } 6 \text { months } \\
\quad=0.26\end{array}$ & Moderate \\
\hline
\end{tabular}




\section{Continued}

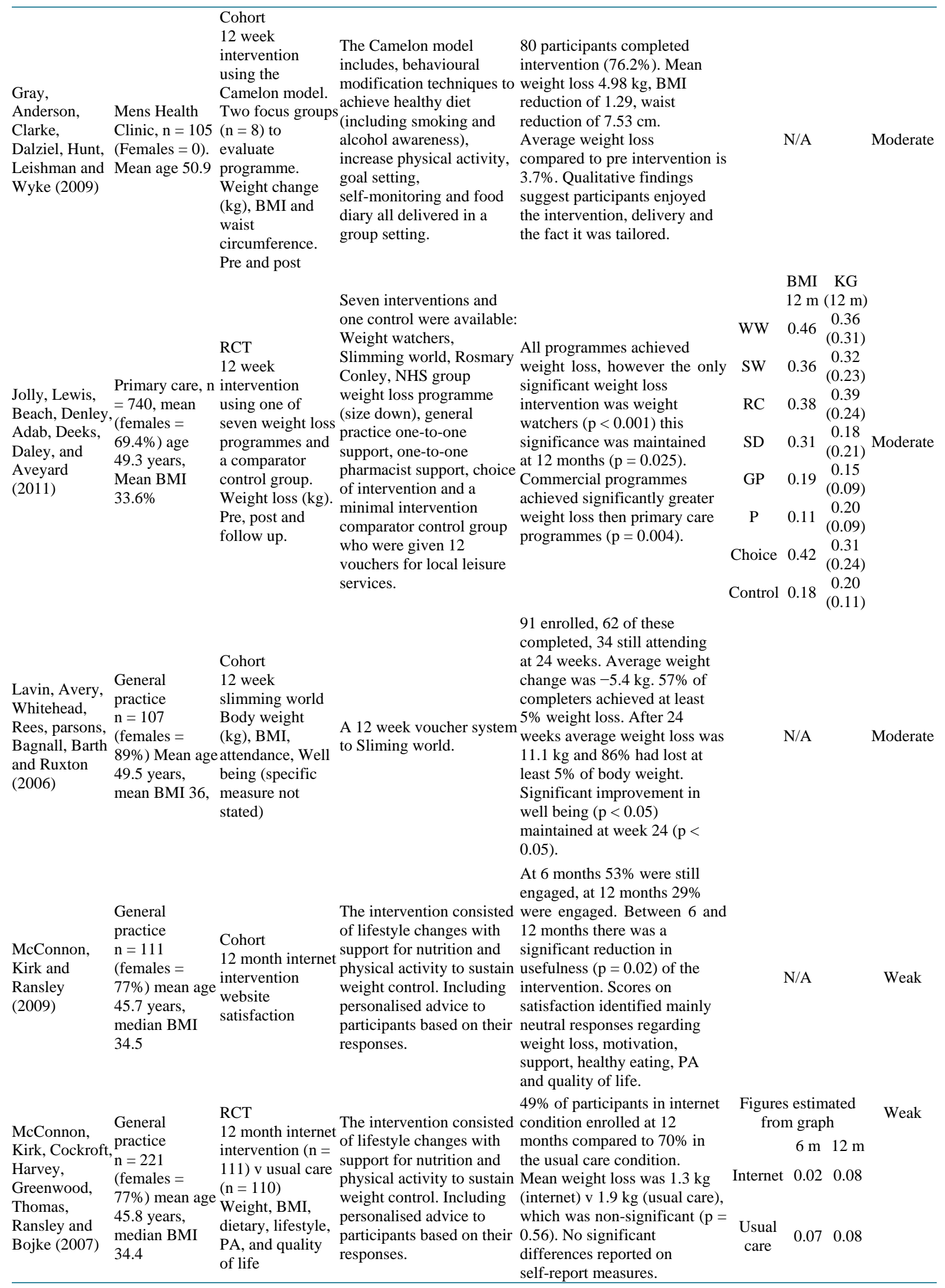




\section{Continued}

\begin{tabular}{|c|c|c|c|c|c|c|c|}
\hline $\begin{array}{l}\text { Packianathan, } \\
\text { Sheikh, Feben } \\
\text { and Finer } \\
\text { (2002) }\end{array}$ & $\begin{array}{l}\text { Referred from } \\
\text { hospital obesity } \\
\text { clinic } \\
\mathrm{n}=45 \text { (females } \\
=45 \text { ). Mean } \\
\text { age } 49.1 \text { years, } \\
\text { mean BMI } \\
37.1 \text {. }\end{array}$ & $\begin{array}{l}\text { Cohort } \\
\text { y } 10 \text { week } \\
\text { intervention with } \\
\text { s } 2 \text { year } \\
\text { maintenance } \\
\text { phase. } \\
\text { Weight, BMI, } \\
\text { EDI-2 }\end{array}$ & $\begin{array}{l}\text { For } 10 \text { weeks a calorie } \\
\text { intake was reduced to } 900 \text {, } \\
\text { with } 2 \text { meal replacements. } \\
\text { Followed by } 2 \text { year } \\
\text { maintenance during which } \\
\text { half maintained meal } \\
\text { replacement and half } \\
\text { received structured diet } \\
\text { plan. }\end{array}$ & $\begin{array}{l}\text { Mean weight loss after } 10 \\
\text { weeks was } 9.7 \mathrm{~kg} \text {, mean } \\
\text { percentage lost was } 9.8 \% \text {. } \\
\text { Of the EDI subscales the } \\
\text { only significant reduction } \\
\text { was body dissatisfaction (p } \\
<0.001 \text { ). } 8 \% \text { of EDI scores } \\
\text { suggest psychological traits } \\
\text { linked to eating disorders. }\end{array}$ & BMI & 0.69 & Moderate \\
\hline $\begin{array}{l}\text { Paxman, Hall, } \\
\text { Harden, } \\
\text { O’Keeffe and } \\
\text { Simper (2011) }\end{array}$ & $\begin{array}{l}\text { General } \\
\text { population } \\
\mathrm{n}=71 \text { (female } \\
=53 \text { ) mean age } \\
45.63 \text { years, } \\
\text { mean BMI } \\
37.29 \text {, mean } \\
\text { weight } 104.8 \\
\text { kg. }\end{array}$ & $\begin{array}{l}\text { Cohort } \\
12 \text { week } \\
\text { intervention-- } \\
\text { Small changes } \\
\text { Weight (kg), } \\
\text { BMI, body fat } \\
\text { (biological } \\
\text { impedance), } \\
\text { waist } \\
\text { circumference, } \\
\text { BP, well-being, } \\
\text { POMS, eating } \\
\text { questionnaire, } \\
\text { cholesterol, } \\
\text { triglycerides and } \\
\text { food diaries. }\end{array}$ & $\begin{array}{l}12 \text { week intervention } \\
\text { called Small Changes. } \\
\text { Session are weekly for } 2 \\
\text { hours facilitated by } \\
\text { experts. Focus included } \\
\text { nutrition, PA, } \\
\text { self-monitoring and goal } \\
\text { settings. Measures taken at } \\
\text { baseline and } 12 \text { weeks. }\end{array}$ & $\begin{array}{l}40 \text { participants completed } \\
\text { intervention. Significant } \\
\text { reduction in weight }(\mathrm{p}< \\
0.005) \text { BMI }(\mathrm{p}<0.005), \\
\text { body fat }(\mathrm{p}=0.019), \text { waist } \\
\text { circumference }(\mathrm{p}=0.008) \text {, } \\
\text { HDL Cholesterol }(\mathrm{p}=0.04) \\
\text { and a total mood }(\mathrm{p}<005) \text {. } \\
\text { A significant improvement } \\
\text { in well-being was noted ( }< \\
\text { 0.005). No significant } \\
\text { change in BP, overall } \\
\text { cholesterol, triglycerides or } \\
\text { glucose. }\end{array}$ & 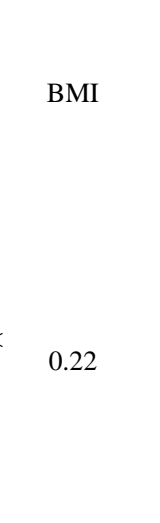 & 0.18 & Weak \\
\hline $\begin{array}{l}\text { Quinn, Doody } \\
\text { and O’Shea } \\
\text { (2008) }\end{array}$ & $\begin{array}{l}\text { Hospital weight } \\
\text { management } \\
\text { service } \mathrm{n}=21 \\
\text { (females }=21) \text {, } \\
\text { mean age }= \\
37.6 \text { years, } \\
\text { mean weight } \\
117.9 \mathrm{~kg}\end{array}$ & $\begin{array}{l}\text { Cohort physical } \\
\text { activity } \\
\text { intervention. } \\
\text { Cardiovascular } \\
\text { fitness, IPAQ, } \\
\text { IWQOL-lite, } \\
\text { APA }\end{array}$ & $\begin{array}{l}16 \text { week physical activity } \\
\text { intervention consisting of } \\
\text { four one hour education } \\
\text { sessions. Sessions } \\
\text { involved understanding the } \\
\text { principals of exercise. }\end{array}$ & $\begin{array}{l}18 \text { completed. No } \\
\text { significant decrease in } \\
\text { weight, or improvement in } \\
\text { IPAQ and IWQOL. } \\
\text { Cardiovascular fitness did } \\
\text { eimprove (p }<0.001 \text { ). } \\
\text { Overall attitude to exercise } \\
\text { was noted as improving }\end{array}$ & \multicolumn{2}{|c|}{$K G=0.04$} & Weak \\
\hline $\begin{array}{l}\text { Sniehotta, } \\
\text { Dombrowski, } \\
\text { Avenell, } \\
\text { Johnston, } \\
\text { McDonald, } \\
\text { Murchie, } \\
\text { Ramsay, } \\
\text { Robertson and } \\
\text { Araujo-Soares } \\
\text { (2011) }\end{array}$ & $\begin{array}{l}\text { Primary care n } \\
=81 \text { (females = } \\
61 \% \text {, mean } \\
\text { age } 56.56 \\
\text { years, mean } \\
\text { BMI = 36.73 }\end{array}$ & $\begin{array}{l}\text { RCT Group } \\
\text { based } \\
\text { intervention (n= } \\
53 \text { ) or a leaflet } \\
\text { control (n=28). } \\
\text { Weight, waist } \\
\text { = circumference, } \\
\text { body fat, BP, HR, } \\
6 \text { minute walk } \\
\text { test, self-reported } \\
\text { PA, self-reported } \\
\text { food frequency, } \\
\text { TPB } \\
\text { questionnaire, } \\
\text { APCPS, ACS, } \\
\text { SSS, IPQ-R }\end{array}$ & $\begin{array}{l}8 \text { week intervention } \\
\text { consisting of } 6 \text { group } \\
\text { sessions. Topics included } \\
\text { goal setting, behavioural } \\
\text { diary, pedometer, PA and } \\
\text {, diet planning, relapse } \\
\text { prevention, } \\
\text { self-monitoring and barrier } \\
\text { prevention. Control group } \\
\text { received standard care and } \\
\text { BHF leaflets contain the } \\
\text { above information. }\end{array}$ & $\begin{array}{l}\text { Questionnaires completed at } \\
\text { baseline, } 3 \text { months and six } \\
\text { months. Significant } \\
\text { reduction in waist } \\
\text { circumference was noted } \\
\text { between the intervention } \\
\text { rand control condition ( } \mathrm{p}= \\
0.047) \text { at baseline and } 6 \\
\text { months, no other significant } \\
\text { differences noted. }\end{array}$ & $\begin{array}{l}\quad(\mathrm{kg}) \\
\text { Intervention } \\
\quad(\mathrm{Kg})\end{array}$ & 0.12 & Moderate \\
\hline
\end{tabular}

$\mathrm{BP}=$ Blood Pressure; HR = heart Rate; RER = respiratory Exchange ratio; $\mathrm{VO}_{2}=$ Oxygen Consumption; EDI-2 = Eating Disorder Inventory 2; IPAQ = International physical Activity questions—short form; IWQOL-Lite = Impact of Weight on Quality of Life Questionnaire-Short form; APA-Attitude to Physical Activity questionnaire; TPB questionnaire = Theory of Planned Behaviour Questionnaire; APCPS = Action Planning and Copping Planning Scales; ACS = Action Control scale; SSS = Social Support Scale; IPQ-R = Illness perception Questionnaire-R. RCT = randomised control trial, CCT = Clinical controlled trial.

withten studies [14]-[17] [20] [21] [23] [26] [33] [34] reporting a reduction in weight (kg) or BMI in adults, with four articles demonstrating no reduction [18] [22] [24] [25]. Of those targeting children, all six reported a reduction in weight $(\mathrm{kg})$ or BMI SDS [27]-[32].

To elaborate, the largest mean reduction in weight was $9.8 \mathrm{~kg}$ recorded through a ten week structured calorie controlled diet plan and management [21]. This followed two studies that demonstrated private sector delivered interventions were effective in producing significant weight loss. More specifically, Lavin et al., (2006) found a mean reduction of $5.4 \mathrm{~kg}$ through Slimming World, whilst the Weight Watchers intervention in Jolly et al. (2011) 
Table 2. Articles relating to childhood obesity.

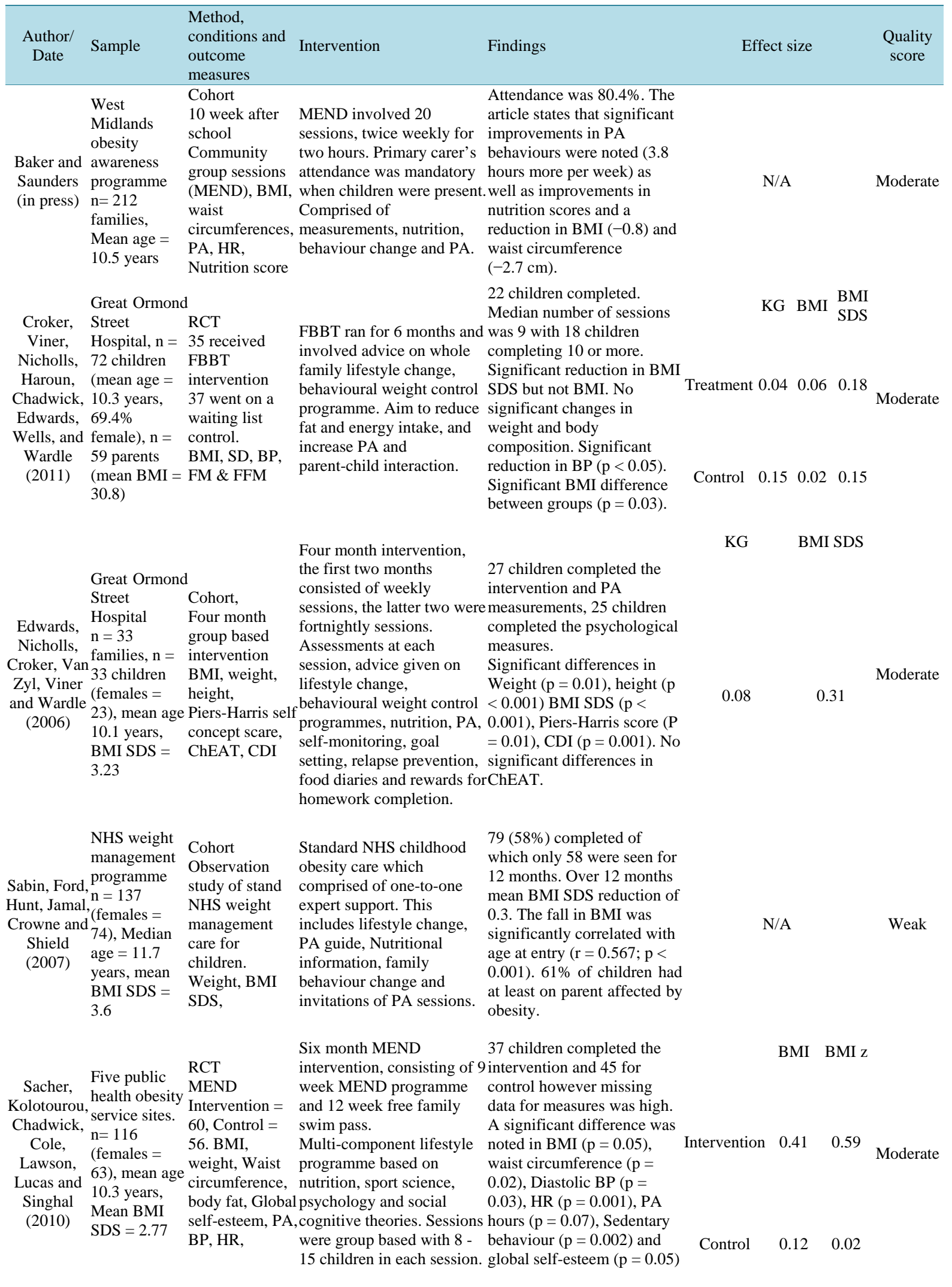




\section{Continued}

\begin{tabular}{|c|c|c|c|c|c|c|c|c|}
\hline $\begin{array}{l}\text { Watson, } \\
\text { Dugdill, } \\
\text { Pickering, } \\
\text { Bostock, } \\
\text { Hargreaves, } \\
\text { Staniford } \\
\text { and Cable } \\
\text { (2011) }\end{array}$ & $\begin{array}{l}\text { Community } \\
\text { based } \\
\text { recruitment } \\
\mathrm{n}=121 \\
\text { families, } \\
\text { mean age } \\
10.17 \text { years, } \\
\text { Mean BMI } \\
\text { SDS = } 2.93 \text {, } \\
\text { mean adult } \\
\text { BMI } 31.35\end{array}$ & $\begin{array}{l}\text { Cohort, GOALS } \\
\text { intervention, } \\
\text { BMI, weight, }\end{array}$ & $\begin{array}{l}\text { GOALS is a family } \\
\text { approach to changing eating } \\
\text { and PA behaviours. } \\
\text { Involved a total of } 18 \text { two } \\
\text { hour group based weekly } \\
\text { sessions after school which } \\
\text { was delivered by specialists } \\
\text { and experts in the field. }\end{array}$ & $\begin{array}{l}60 \text { families completed over } \\
50 \% \text { of the sessions } \\
\text { consisting of } 47 \text { children. } \\
70 \% \text { of children reduced } \\
\text { BMI with mean change of } \\
0.09 \text { (p }<0.001 \text { ). For } 26 \text { of } \\
\text { these children at } 12 \text { months } \\
\text { weight reduction had been } \\
\text { maintained. Children whose } \\
\text { family member reduced } \\
\text { BMI showed a significantly } \\
\text { larger decrease in BMI SDS } \\
\text { (p }<0.01 \text { ), which was not } \\
\text { maintained at } 12 \text { month } \\
\text { follow up. }\end{array}$ & $\begin{array}{c}\mathrm{C}+\text { follow } \\
\text { up }\end{array}$ & $\begin{array}{c}\text { BMI } \\
\text { post } \\
(12 \mathrm{~m})\end{array}$ & $\begin{array}{l}\text { BMI } \\
\text { SDS } \\
\text { post } \\
(12 \mathrm{~m})\end{array}$ & Weak \\
\hline
\end{tabular}

MEND = Mind Exercise Nutrition Do It!; HR = Heart Rate; PA = Physical Activity; CDI = Children’s Depression Inventory; ChEAT = Children's Eating Attitudes Test; GOALS = Getting Our Active Lifestyles Started; FM = Fat mass; FFM = fat Free Mass.

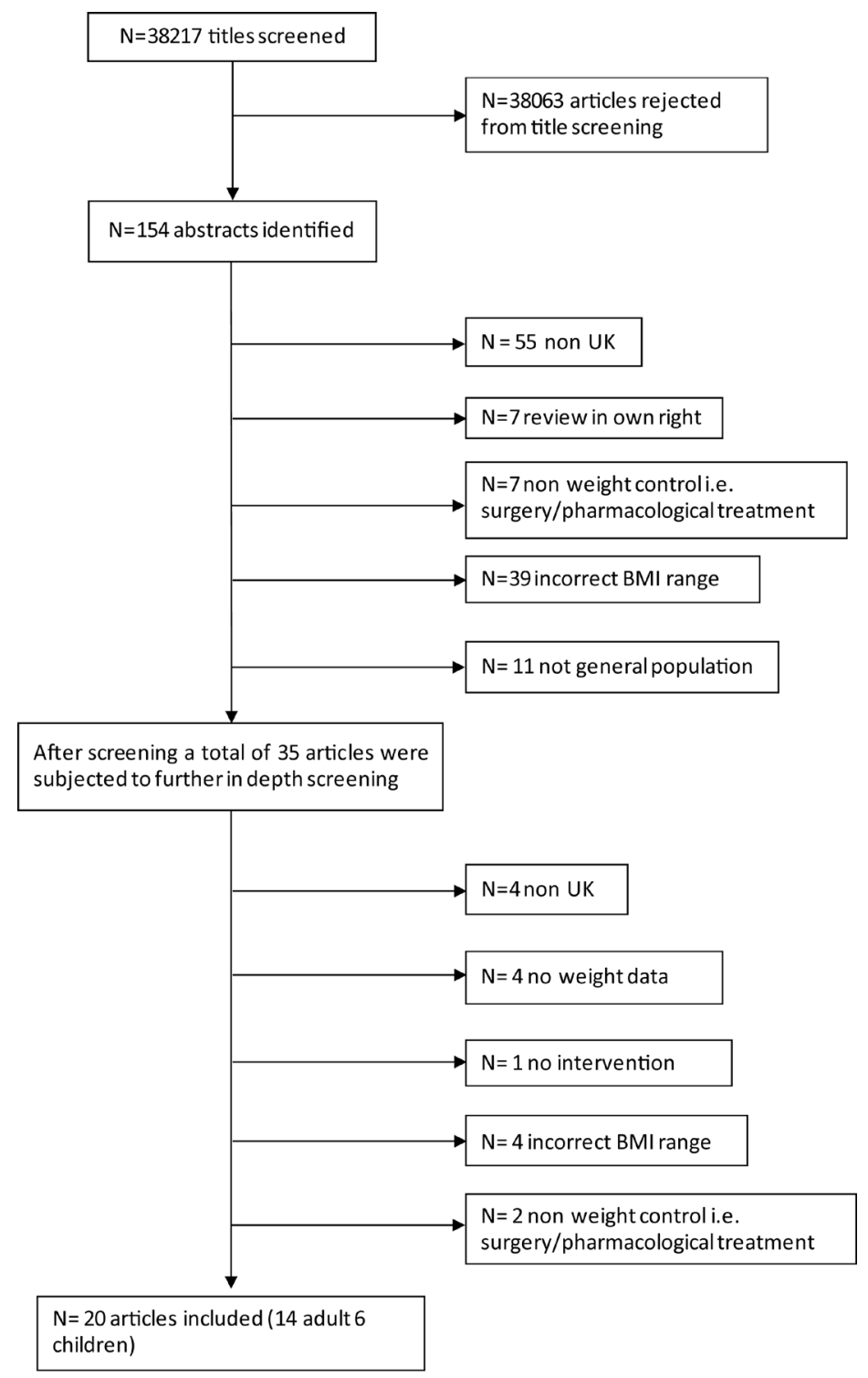

Figure 1. Flow diagram of the selection process of research articles. 
reported a mean loss of $4.43 \mathrm{~kg}$. The duration of these private sector interventions was twelve weeks.

\subsection{Cost Effectiveness}

Despite the cost of intervention delivery being a key factor in the adoption and success of the intervention this was rarely reported. From the twenty studies reviewed, only three adult articles documented evidence of the costs of delivering the intervention [15] [16] [33]. McConnon et al., (2007) noted that the cost per person for an Internet-based intervention was $£ 992.40$ vs. $£ 276.12$ for usual care. The Internet intervention consisted of key lifestyle behavioural changes, however, in terms of weight loss, the internet intervention was less effective than usual care whilst dropout was higher. It is assumed the substantially higher cost of the Internet-based intervention is due to initial start-up costs and design of the website. In comparison, Lavin et al., (2006) reported costs of $£ 44.50$ per person with PCT discount, plus an additional $£ 7$ for GP support. This intervention took advantage of private sector delivery as participants attended Slimming World for twelve weeks. In addition to the weight loss of $5.4 \mathrm{~kg}$ reported above, dropout rates were low, and for those remaining at 24 weeks average weight loss was $11.1 \mathrm{~kg}$. Finally, Jolly et al. (2011) reported costs for each of the six interventions assessed. Costs were as follows: Weight Watchers £55, Slimming World £49.50, Rosemary Conley £55, NHS “Size Down” £70, GP care $£ 90.86$, Pharmacy $£ 90.43$ (all programmes had an additional cost of £21.87 for administrative costs). Three of the interventions were privately run and three were publicly delivered, hence, the average total cost for the three private sector programmes equalled £75.04, with public sector programmes averaging £105.63, per person. Whilst these conclusions should be noted with caution due to only three studies reporting cost-effectiveness, private sector programmes appear to be the most cost effective.

\subsection{Quality Score}

A quality score was undertaken on all papers. The "Effective Public Health Practice Project Quality Assessment Tool" [11] was used to assess various elements of each article including, selection bias, study design, confounders, blinding, data collection methods, and dropouts. Of the adult articles, no study scored a strong rating, six scored moderate, and eight scored weak (see Table 1 for more detail). In regard to the child studies, no study scored strong, four were moderate, and two scored weak (see Table 2 for more detail).

\subsection{Meta-Regression Analysis (MRA)}

The further explore the data, MRA was undertaken. Limited reporting of data restricted data analysis. When appropriate data were present, effect size calculations were undertaken using the approach described by Cohen (1988). Effect sizes were calculated for BMI as this was the most consistently reported information. Due to these inconsistencies, only seven studies were included in this stage of analysis (three children and four adult). A total of 19 effect sizes were computed from these seven studies (see Table $1 \&$ Table 2). For studies that reported multiple effect sizes these were weighted accordingly, to minimise the influence of bias.

\subsection{Preliminary Meta-Analysis}

Results from 19 BMI effect size calculations reported in the seven studies with usable measurements were analysed. Given the aim of the interventions is to reduce BMI, successful interventions are signified by a negative effect size. Hence, within the range of reported effect sizes, the more negative the more successful. The funnel plot (Figure 2) shows the results reported from studies with smaller sample sizes (vertical axis) giving the most widely scattered range of effect size (horizontal axis) while those from studies with larger sample sizes lie within a narrower range, which are more or less evenly distributed around the sample mean effect size of -0.28 (which is reported in Table 3).

According to sampling theory, larger-sample estimates should be more precise than smaller-sample estimates, with the precision of estimates varying in proportion to the square root of sample size. As such, the funnel plot in Figure 2 suggests that this literature is reliable in its findings and does not suffer from undue publication bias. Because there is no clear tendency for small sample studies (i.e. those with low square root of sample size) to cluster on one side or other of the mean, we conclude that there is likewise no systematic tendency in the literature to over- or under-report effect sizes. Moreover, BMI effect sizes reported by the study with the largest sample lies within the 95 percent confidence interval around the mean reported in Table 3. This preliminary analysis 


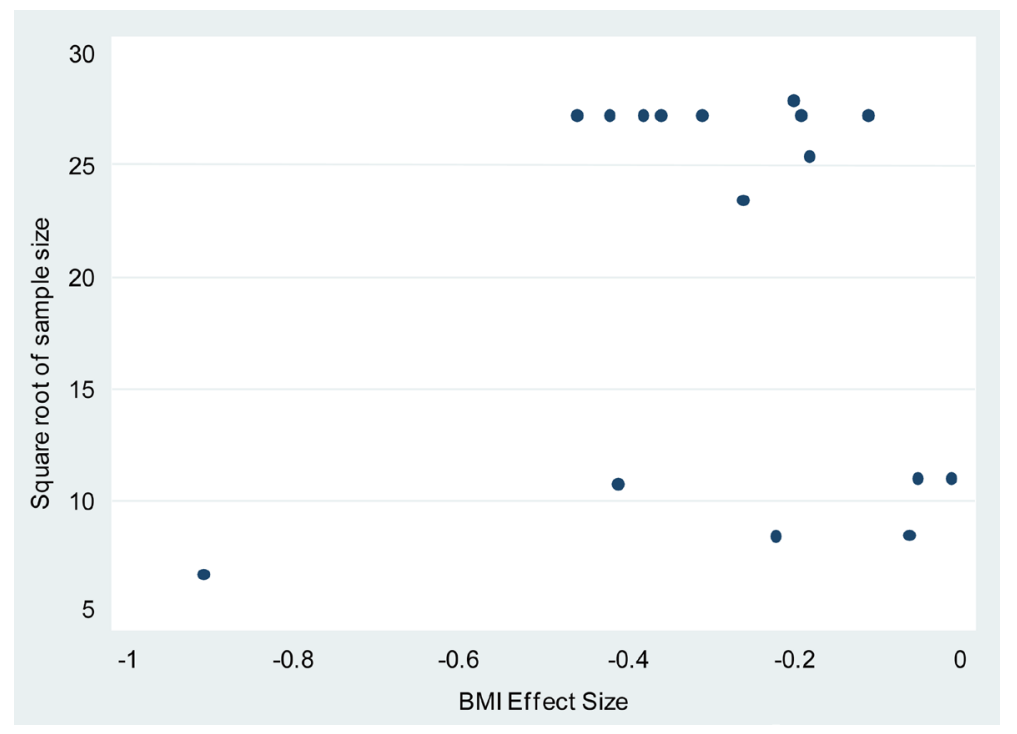

Figure 2. Funnel plot. Note: excluding three values from RCT control groups; hence, 16 observations.

Table 3. Descriptive statistics for BMI effect size.

\begin{tabular}{ccc} 
Mean & \multicolumn{2}{c}{$95 \%$ Confidence Interval } \\
\hline-0.28 & -0.40 & -0.17 \\
\hline
\end{tabular}

Note: excluding three values from RCT control groups; hence, 16 observations.

suggests that the typical weight management intervention is successful in achieving a mean BMI effect size of around -0.28 , which is significant in comparison to zero $(\mathrm{p}<0.001)$.

\subsection{Meta-Regression Analysis}

Regression analysis using ordinary least squares (OLS) was used to regress the dependent variable-BMI effect size - on a range independent variables. The guiding principle in MRA is that parsimonious models are preferred, particularly when using small data sets (as in the current study). As such the independent variables were reduced to simple binary values (i.e., 0,1 or 2). For each variable an omitted category was used as a comparison, these were Completion_3m to indicate completion of the intervention including a 3 month follow up, with a reference category of those with follow up results at six and 12 months; Methodology_RCT for those with RCT design, with the reference category consisting of cohort studies; Treatment for all treatment condition effects arising from RCT studies, the reference category was control groups; Quality_1 to indicate study quality score; Adult to differentiate between adults and child articles; Private_2 to identify publicly funded but privately provided interventions, the reference category consisted of all programmes funded and provided by the public sector.

The estimated regression coefficients reported in Table 4 measure the effect of the state of each binary variable relative to its reference category (or categories), or of a one unit change in the square root of the sample size (SqRt_SS). Individually, the coefficients all have sensible interpretations and, with one exception, with five relationships differing significantly. The positive coefficient on the square root of the sample size (SqRt_SS) means that as the sample size rises so reported effect sizes become, other factors held constant, less negative ${ }^{1}$. This suggests that large sample size acts to attenuate what otherwise are likely to be excessively large reported effects. The estimated coefficient on Completion_3M is not statistically significant, but does suggest that intervention effects are smaller (i.e. less negative) when measured at completion or after three months than when

\footnotetext{
${ }^{1}$ The positive coefficient does not imply that the effect sizes are necessarily positive; the estimated effect size depends also on all the influences on effect size in the model.
} 
Table 4. Meta-regression analysis of the UK literature on interventions to reduce obesity.

\begin{tabular}{cc}
\hline Dependent variable & BMI \\
\hline SqRt_SS & 0.034 \\
Completion_3M & $0.25)^{* *}$ \\
Methodology_RCT & $(1.44)$ \\
& 0.382 \\
Treatment & $(2.60)^{*}$ \\
& -0.296 \\
Quality_1 & $(1.70)$ \\
& -0.491 \\
Adult & $(4.14)^{* * *}$ \\
& -0.382 \\
Private_2 & $(3.22)^{* *}$ \\
& -0.190 \\
_cons & $(1.77)$ \\
Observations & -0.346 \\
F (7, 11) & $(3.39)^{* *}$ \\
19 & 17.07 \\
\hline
\end{tabular}

Note: t-statistics in parentheses (computed from cluster-robust standard errors which, in spite of the small sample size, are larger than the default standard errors and so provide a conservative approach to inference) ${ }^{* *} \mathrm{p}<0.05 ;{ }^{* *} \mathrm{p}<0.01$.

they are measured after either six or 12 months. This is consistent with intervention effects increasing after the intervention rather than falling away.

With respect to the effect of research methodology on reported results, the coefficients on Methodology_RCT and Treatment should be jointly interpreted: the former measures the general effect of RCT methodology (including on control group effects), whereas the latter measures the effect of RCT methodology only on the effect sizes measured for treatment groups (i.e. excluding control group effects). As such, RCT methodology yields a much smaller (i.e. less negative) effect size compared to cohort studies, but this effect is much less dramatic when considered in the light of the effects on treatment groups only. The combined effect of these two variables is still positive (0.086), although not statistically different from zero $(p=0.529)$. (But note that when the sum of two or more coefficients is in the direction of zero, the precision threshold for rejection rises.). The overall result for these two variables suggests that effect sizes obtained from RCT will be almost nine percentage points smaller-less negative - than those obtained from other methodologies. In other words, cohort studies typically report higher effect sizes which may exaggerate the effect in comparison to the more robust RCT. Conversely, and reassuringly, the estimated coefficient on Quality_1 suggests that higher quality studies, other factors held constant, yield substantially larger effect sizes than do lower quality studies.

The final two results may be important from a policy perspective:

1. One striking result is the greater efficacy of interventions targeted to adults (Adult) compared to those for children. Other influences held constant, adults' interventions generally have a strong effect size by -0.382 ; i.e., other influences held constant, some 38 percentage points more effective.

2. One clear policy implication is that private-sector delivery is more effective than public-sector provision. Other influences held constant, private sector interventions generally have a greater effect size of about -0.190 in comparison to public sectors interventions. However, all three of the privately delivered programmes singled out for analysis come from one study, so this finding should be treated with caution (or, better, as a guideline for 
further research, which is one of the purposes of MRA).

Next, the results as a whole are considered to draw a broad conclusion. All of the indicator variables act in relation to the constant term. Consequently, the combined effect size implied by the constant and all the binary indicator variables is given by their sum. Therefore for a study with a mean sample size, all factors held constant, an effect size of 0.50 would be expected. Finally, we issue a word of caution. This is a small sample study. Although ordinary least squares (OLS) was used for this analysis, which has known and useful small sample characteristics, appropriate technique cannot substitute for data. Hence, these results should be taken as indicative.

\section{Discussion}

This systematic review with additional MRA explored the effect of UK weight management interventions on reductions in weight and BMI in adults and children. The majority of the research articles identified a significant reduction in weight and/or BMI following engagement in a PA or diet-based intervention for both adult and children populations, supporting previous reviews [8] [9].

As noted previously, the largest reduction in weight was $9.8 \mathrm{~kg}$ recorded through a structured calorie controlled diet plan and management [21]. This was closely followed by Lavin et al., (2006) who reported a reduction of $5.4 \mathrm{~kg}$ through Slimming World, whilst the Weight Watchers intervention in Jolly et al., (2011) reported a loss of $4.43 \mathrm{~kg}$. In conjunction with the results from the MRA, the most effective interventions were lifestyle programmes that targeted PA levels and diet management. This is something future interventions need to include.

The financial costs of interventions are often of great interest to policy makers. Yet, despite this, only three articles consider the costs of interventions [15] [16] [33]. The findings of these three studies and of the MRA reported above are consistent in suggesting the worthwhile adoption of private sector interventions that are already in place, such as Weight Watchers and Slimming World, due to their cost effectiveness, efficacy in reducing weight/BMI, and reduced dropout rates. Thus, private sector programmes may be particularly beneficial from a variety of policy considerations. However, typically private programmes are compared to NHS provisions whose effectiveness is not guaranteed. In particular research does not detail the specific content of public sector interventions, thus we are unaware if these have been optimised. No costs for childhood interventions were noted.

Overall, the review indicates a higher incidence of weight management interventions for adult populations compared to children, together with a wider variety of types of interventions. This is perhaps unsurprising given that childhood obesity interventions are still at a very early stage in their development. Despite this, obesity in children is stated as one of the most serious challenges in the $21^{\text {st }}$ century [3] and the present review highlights that further research into the design, delivery and effectiveness of childhood weight management interventions in the UK is needed. The MRA specifically noted that interventions focusing on adults were generally more effective than those with child participants. However, interventions that encompass the entire family appear the most successful in reducing childhood obesity, which also support previous findings [3].

The interventions employed in the studies varied in length (2 - 6 months), although the majority were twelve weeks. It may also be worth noting that despite the tendency to implement a weight management programme for twelve weeks; most interventions reported a reduction in weight/BMI at completion. As such there is no certainty as to how well these programmes help patients in the crucial area of maintaining weight loss. It is at the stage of completion that issues arose with maintenance, with substantial drop-out of participants between completion and follow-up/maintenance data collection. Corresponding with previous literature, no intervention offered support to participants following completion. Nevertheless, it is at this point individuals appear to need further support, to reduce remission. In short, this highlights the importance of offering continuous support to maintain weight reductions and provides an interesting area of future research.

Overall, it is noteworthy that none of the interventions delivered were explicitly underpinned by theory. Future interventions may be able to improve success if developed interventions were informed by theoretical knowledge. However, a recent review suggested that interventions developed using the transtheoretical model have not conclusively found significant changes, especially after 12 months [35]. Despite this, developing and implementing weight management interventions that are informed by theoretical frameworks may increase the likelihood of successful and maintained weight loss [36]. 


\subsection{Further Research}

It would be useful for future investigations to consider paying more attention to childhood interventions, since this is an area of high concern and only recently appears to have been documented in the literature. This would be particularly useful in the UK to allow policy makers to have an accurate point of reference. It would also be of interest for future research to investigate the association between theoretical concepts and the development of interventions as theoretical underpinning is likely to increase success. Maintaining weight loss appears to be an issue of high concern; most studies predominately implemented a 12 week intervention, which offers little insight into long term weight loss. Aligned with this, further research may wish to look closer at public sector programmes, particularly regarding optimisation of these interventions, which has not been clearly established in previous research.

An empirical concern highlighted from this review is the strength of previous research studies. Overall, the quality of most UK-based studies appears to be poor, as made evident by both the quality scoring and by the paucity of observations available for MRA. Although the high number of cohort based studies was not surprising, further RCT or CCT would be beneficial. In addition, focus needs to be paid to statistical analysis, as it was evident that the level of analysis in most of the noted studies was limited at best. Enhanced statistical quality could also benefit future MRA.

\subsection{Limitations}

Unlike previous reviews the current review only focused on UK based articles. This did significantly limit access to papers as many high quality articles have been published outside of the UK. Despite this, the present review details a specific focus of the effectiveness of UK weight management interventions. Furthermore, the MRA was limited to BMI reductions rather than weight loss, as so few studies published the data to calculate effect sizes.

\subsection{Concluding Remarks}

In conclusion, the findings suggest that weight management interventions within the UK are effective in reducing weight and/or BMI for both children and adults typically for a duration of 12 weeks. From this it can be identified that the most effective approaches are delivered in the private sector, targeting both diet and PA levels, whilst effectiveness is further improved with child populations if programmes include parents and children. It is important to note that previous research is not explicit in detailing the optimisation of public health interventions.

\section{Author Statements}

My co-authors and I do not have any interests that might be interpreted as influencing the research, and APA ethical standards were followed in the conduct of the study. Data from this study have not previously been published or presented, and we feel the information contained adds significantly to the field. Ethical approval for the research was granted by Staffordshire University ethics board. The project was funded by Shropshire Country Primary care trust.

\section{References}

[1] The NHS Information Centre Lifestyle Statistics (2009) Statistics on Besity, Physical Activity and Diet London: The Health and Social care information Centre.

[2] Health Survey for England (2012) Statistics on Obesity, Physical Activity and Diet: England 2010. The Health and Social Care Information Centre, p. 119.

[3] Watson, P., Dugdill, L., Murphy, R., Knowles, Z. and Cable, N. (2013) Moving forward in Childhood Obesity Treatment: A Call for Translational Research. Health Education Journal, 72, 230-239. http://dx.doi.org/10.1177/0017896912438313

[4] Lean, M.E., Han, T.S. and Seidell, J.C. (1999) Impairment of Health and Quality of Life Using New US Federal Guidelines for the Identification of Obesity. Archives of Internal Medicine, 159, 837. http://dx.doi.org/10.1001/archinte.159.8.837

[5] Must, A., Spadano, J., Coakley, E.H., Field, A.E., Colditz, G. and Dietz, W.H. (1999) The Disease Burden Associated 
with Overweight and Obesity. JAMA: The Journal of the American Medical Association, 282, 1523-1529. http://dx.doi.org/10.1001/jama.282.16.1523

[6] Roberts, C.K. and Barnard, R.J. (2005) Effects of Exercise and Diet on Chronic Disease. Journal of Applied Physiology, 98, 3-30. http://dx.doi.org/10.1152/japplphysiol.00852.2004

[7] Calise, T.V. and Martin, S. (2010) Assessing the Capacity of State Physical Activity Programs—A Baseline Perspective. Journal of Physical Activity \& Health, 7, 119.

[8] Goldberg, J.H. and King, A.C. (2007) Physical Activity and Weight Management across the Lifespan. Annual Review of Public Health, 28, 145-170. http://dx.doi.org/10.1146/annurev.publhealth.28.021406.144105

[9] Teixeira, P.J., Silva, M.N., Mata, J., Palmeira, A.L. and Markland, D. (2012) Motivation, Self-Determination, and Long-Term Weight Control. International Journal of Behavioral Nutrition and Physical Activity, 9, 1-13.

[10] Fiese, B.H., Hammons, A. and Grigsby-Toussaint, D. (2012) Family Mealtimes: A Contextual Approach to Understanding Childhood Obesity. Economics \& Human Biology, 10, 365-74. http://dx.doi.org/10.1016/j.ehb.2012.04.004

[11] Thomas, B., Ciliska, D., Dobbins, M. and Micucci, S. (2004) A Process for Systematically Reviewing the Literature: Providing the Research Evidence for Public Health Nursing Interventions. Worldviews on Evidence-Based Nursing, 1, 176-184. http://dx.doi.org/10.1111/j.1524-475X.2004.04006.x

[12] Thomas, B.H., Ciliska, D., Dobbins, M. and Micucci, S. (2004) A Process for Systematically Reviewing the Literature: Providing the Research Evidence for Public Health Nursing Interventions. Worldviews on Evidence-Based Nursing, 1, 176-184. http://dx.doi.org/10.1111/j.1524-475X.2004.04006.X

[13] Armijo-Olivo, S., Stiles, C.R., Hagen, N.A., Biondo, P.D. and Cummings, G.G. (2012) Assessment of Study Quality for Systematic Reviews: A Comparison of the Cochrane Collaboration Risk of Bias Tool and the Effective Public Health Practice Project Quality Assessment Tool: Methodological Research. Journal of Evaluation in Clinical Practice, 18, 12-18. http://dx.doi.org/10.1111/j.1365-2753.2010.01516.x

[14] Gray, C.M., Anderson, A.S., Clarke, A.M., Dalziel, A., Hunt, K., Leishman, J., et al. (2009) Addressing Male Obesity: An Evaluation of a Group-Based Weight Management Intervention for Scottish Men. Journal of Men's Health, 6, 70-81. http://dx.doi.org/10.1016/j.jomh.2008.11.002

[15] Jolly, K., Lewis, A., Beach, J., Denley, J., Adab, P., Deeks, J.J., et al. (2011) Comparison of Range of Commercial or Primary Care Led Weight Reduction Programmes with MINIMAL intervention Control for Weight Loss in Obesity: Lighten up Randomised Controlled Trial. BMJ: British Medical Journal, 343.

[16] Lavin, J., Avery, A., Whitehead, S., Rees, E., Parsons, J., Bagnall, T., et al. (2006) Feasibility and Benefits of Implementing a Slimming on Referral Service in Primary Care Using a Commercial Weight Management Partner. Public Health, 120, 872-881. http://dx.doi.org/10.1016/j.puhe.2006.05.008

[17] Laws, R. (2004) A New Evidence-Based Model for Weight Management in Primary Care: The Counterweight Programme. Journal of Human Nutrition and Dietetics, 17, 191-208. http://dx.doi.org/10.1111/j.1365-277X.2004.00517.x

[18] McConnon, Á., Kirk, S.F. and Ransley, J.K. (2009) Process Evaluation of an Internet-Based Resource for Weight Control: Use and Views of an Obese Sample. Journal of Nutrition Education and Behavior, 41, 261-267. http://dx.doi.org/10.1016/j.jneb.2008.07.008

[19] McCormick, B. and Stone, I. (2007) Economic Costs of Obesity and the Case for Government Intervention. Obesity Reviews, 8, 161-164. http://dx.doi.org/10.1111/j.1467-789X.2007.00337.x

[20] McQuigg, M., Brown, J., Broom, J., Laws, R., Reckless, J., Noble, P., et al. (2005) Empowering Primary Care to Tackle the Obesity Epidemic: The Counterweight Programme. European Journal of Clinical Nutrition, 59, S93. http://dx.doi.org/10.1038/sj.ejcn.1602180

[21] Packianathan, I.C., Sheikh, M., Feben, S. and Finer, N. (2002) The Eating Disorder Inventory in a UK National Health Service Obesity Clinic and Its Response to Modest Weight Loss. Eating Behaviors, 3, 275-284. http://dx.doi.org/10.1016/S1471-0153(02)00063-6

[22] Quinn, A., Doody, C. and O’Shea, D. (2008) The Effect of a Physical Activity Education Programme on Physical Activity, Fitness, Quality of Life and Attitudes to Exercise in Obese Females. Journal of Science and Medicine in Sport, 11, 469-472. http://dx.doi.org/10.1016/j.jsams.2007.07.011

[23] Ross, H., Laws, R., Reckless, J. and Lean, M. (2008) Evaluation of the Counterweight Programme for Obesity Management in Primary Care: A Starting Point for Continuous Improvement. The British Journal of General Practice, 58, 548-554. http://dx.doi.org/10.3399/bjgp08X319710

[24] Sniehotta, F.F., Dombrowski, S.U., Avenell, A., Johnston, M., McDonald, S., Murchie, P., Ramsay, C.R., Robertson, K. and Araujo-Soares, V. (2011) Randomised Controlled Feasibility Trial of an Evidence-Informed Behavioural Intervention for Obese Adults with Additional Risk Factors. PloS ONE, 6, Article ID: e23040. http://dx.doi.org/10.1371/journal.pone.0023040 
[25] Carroll, S., Marshall, P., Borkoles, E., Ingle, L., Barker, D. and Tan, L.B. (2007) Efficacy of Lifestyle Intervention on Peak Exercise Cardiac Power Output and Reserve in Premenopausal Obese Females: A Randomised Pilot Study. International Journal of Cardiology, 119, 147-155. http://dx.doi.org/10.1016/j.ijcard.2006.07.099

[26] Paxman, J.R., Hall, A.C., Harden, C.J., O’Keeffe, J. and Simper, T.N. (2011) Weight Loss Is Coupled with Improvements to Affective State in Obese Participants Engaged in Behavior Change Therapy Based on Incremental, Self-Selected “Small Changes”. Nutrition Research, 31, 327-337. http://dx.doi.org/10.1016/j.nutres.2011.03.015

[27] Croker, H., Viner, R.M., Nicholls, D., Haroun, D., Chadwick, P., Edwards, C., Wells, J.C.K. and Wardle, J. (2011) Family-Based Behavioural Treatment of Childhood Obesity in a UK National Health Service Setting: Randomized Controlled Trial. International Journal of Obesity, 36, 16-26. http://dx.doi.org/10.1038/ijo.2011.182

[28] Edwards, C., Nicholls, D., Croker, H., Van Zyl, S., Viner, R. and Wardle, J. (2005) Family-Based Behavioural Treatment of Obesity: Acceptability and Effectiveness in the UK. European Journal of Clinical Nutrition, 60, 587-592. http://dx.doi.org/10.1038/sj.ejcn.1602353

[29] Sabin, M.A., Ford, A., Hunt, L., Jamal, R., Crowne, E.C. and Shield, J.P. (2007) Which Factors Are Associated with a Successful Outcome in a Weight Management Programme for Obese Children? Journal of Evaluation in Clinical Practice, 13, 364-368. http://dx.doi.org/10.1111/j.1365-2753.2006.00706.x

[30] Baker, J. and Saunders, K. (2012) Fitter, Healthier, Happier Families: A Partnership to Treat Childhood Obesity in the West Midlands. Public Health, 126, 332-334. http://dx.doi.org/10.1016/j.puhe.2012.01.013

[31] Sacher, P.M., Kolotourou, M., Chadwick, P.M., Cole, T.J., Lawson, M.S., Lucas, A. and Singhal, A. (2010) Randomized Controlled Trial of the MEND Program: A Family-Based Community Intervention for Childhood Obesity. Obesity, 18, S62-S68. http://dx.doi.org/10.1038/oby.2009.433

[32] Watson, P.M., Dugdill, L., Pickering, K., Bostock, S., Hargreaves, J., Staniford, L. and Cable, N.T. (2011) A Whole Family Approach to Childhood Obesity Management (GOALS): Relationship between Adult and Child BMI Change. Annals of Human Biology, 38, 445-452. http://dx.doi.org/10.3109/03014460.2011.590531

[33] McConnon, Á., Kirk, S.F., Cockroft, J.E., Harvey, E.L., Greenwood, D.C., Thomas, J.D., Ransley, J.K. and Bojke, L. (2007) The Internet for Weight Control in an Obese Sample: Results of a Randomised Controlled Trial. BMC Health Services Research, 7, 206. http://dx.doi.org/10.1186/1472-6963-7-206

[34] Ahern, A.L., Olson, A.D., Aston, L.M. and Jebb, S.A. (2011) Weight Watchers on Prescription: An Observational Study of Weight Change among Adults Referred to Weight Watchers by the NHS. BMC Public Health, 11, 434. http://dx.doi.org/10.1186/1471-2458-11-434

[35] Tuah, N., Amiel, C., Qureshi, S., Car, J., Kaur, B. and Majeed, A. (2011) Transtheoretical Model for Dietary and Physical Exercise Modification in Weight Loss Management for Overweight and Obese Adults. Cochrane Database System Review, 10, 1-73. http://dx.doi.org/10.1002/14651858.CD008066.pub2

[36] Hutchison, A.J., Breckon, J.D. and Johnston, L.H. (2009) Physical Activity Behavior Change Interventions Based on the Transtheoretical Model: A Systematic Review. Health Education \& Behavior, 36, 829-845.

http://dx.doi.org/10.1177/1090198108318491 